Provided for non-commercial research and education use. Not for reproduction, distribution or commercial use.

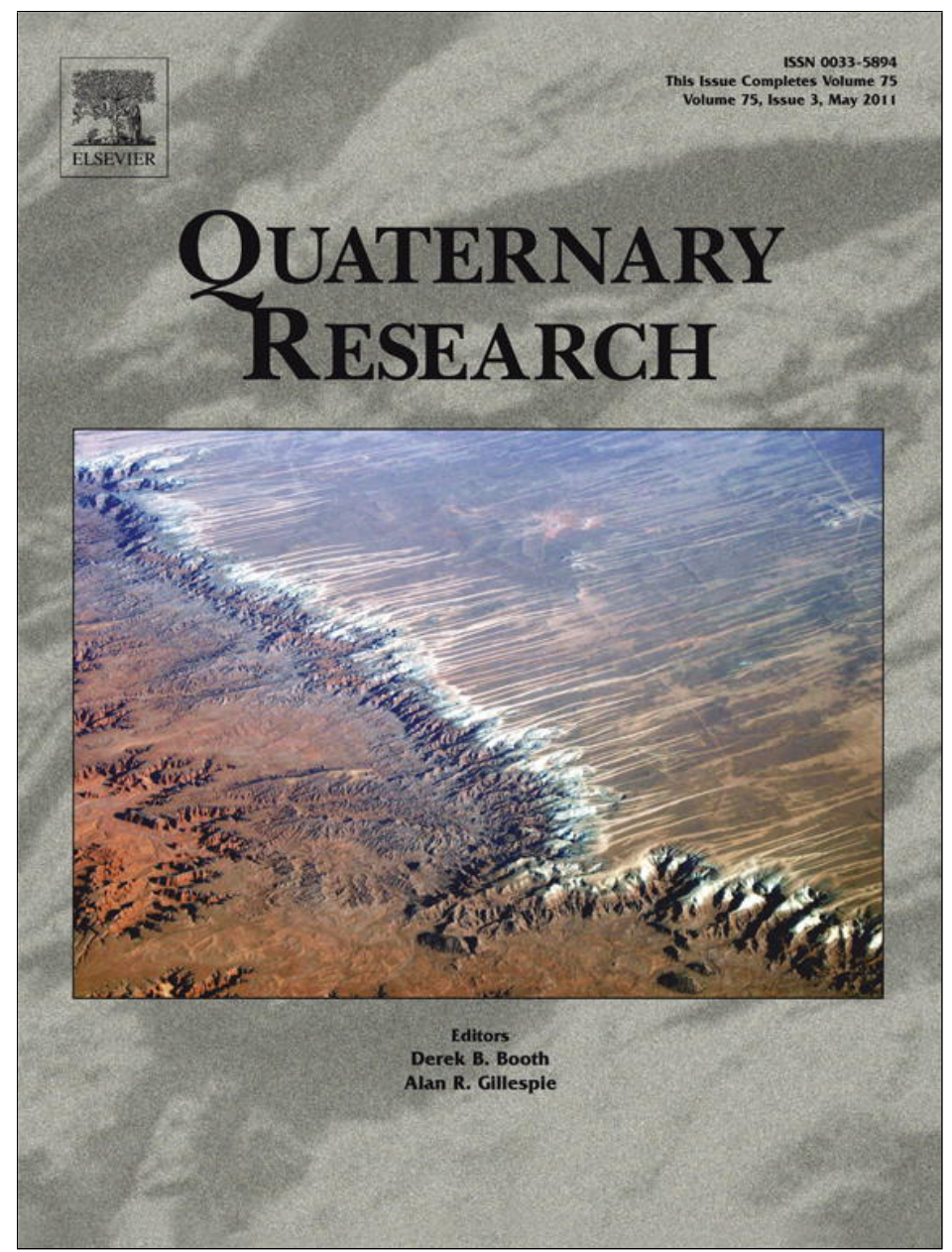

This article appeared in a journal published by Elsevier. The attached copy is furnished to the author for internal non-commercial research and education use, including for instruction at the authors institution and sharing with colleagues.

Other uses, including reproduction and distribution, or selling or licensing copies, or posting to personal, institutional or third party websites are prohibited.

In most cases authors are permitted to post their version of the article (e.g. in Word or Tex form) to their personal website or institutional repository. Authors requiring further information regarding Elsevier's archiving and manuscript policies are encouraged to visit:

http://www.elsevier.com/copyright 


\title{
A chironomid-based reconstruction of summer temperatures in NW Iceland since AD 1650
}

\author{
P.G. Langdon ${ }^{\mathrm{a}, *}$, C.J. Caseldine ${ }^{\mathrm{b}}$, I.W. Croudace ${ }^{\mathrm{c}}$, S. Jarvis ${ }^{\mathrm{c}}$, S. Wastegård ${ }^{\mathrm{d}}$, T.C. Crowford ${ }^{\mathrm{a}}$ \\ a School of Geography, University of Southampton, Highfield, Southampton SO17 1BJ, UK \\ b Department of Geography, University of Exeter, Cornwall Campus, Treliever Road, Penryn, Cornwall TR10 9EZ, UK \\ ${ }^{c}$ National Oceanography Centre Southampton, School of Ocean and Earth Sciences, University of Southampton, Waterfront Campus, European Way, Southampton SO14 3ZH, UK \\ d Department of Physical Geography and Quaternary Geology, Stockholm University, SE-106 91 Stockholm, Sweden
}

\section{A R T I C L E I N F O}

\section{Article history:}

Received 16 March 2010

Available online 24 December 2010

\section{Keywords:}

Iceland

Chironomid

Little Ice Age (LIA)

Summer temperature

Lake sediment

\begin{abstract}
A B S T R A C T
Few studies currently exist that aim to validate a proxy chironomid-temperature reconstruction with instrumental temperature measurements. We used a reconstruction from a chironomid percentage abundance data set to produce quantitative summer temperature estimates since AD 1650 for NW Iceland through a transfer function approach, and validated the record against instrumental temperature measurements from Stykkishólmur in western Iceland. The core was dated through Pb-210, Cs-137 and tephra analyses (Hekla 1693) which produced a well-constrained dating model across the whole study period. Little catchment disturbance, as shown through geochemical (Itrax) and loss-on-ignition data, throughout the period further reinforce the premise that the chironomids were responding to temperature and not other catchment or within-lake variables. Particularly cold phases were identified between AD 16831710, AD 1765-1780 and AD 1890-1917, with relative drops in summer temperatures in the order of $1.5-2^{\circ} \mathrm{C}$. The timing of these cold phases agree well with other evidence of cooler temperatures, notably increased extent of Little Ice Age (LIA) glaciers. Our evidence suggests that the magnitude of summer temperature cooling $\left(1.5-2^{\circ} \mathrm{C}\right)$ was enough to force LIA Icelandic glaciers into their maximum Holocene extent, which is in accordance with previous modelling experiments for an Icelandic ice cap (Langjökull).
\end{abstract}

(c) 2010 University of Washington. Published by Elsevier Inc. All rights reserved.

\section{Introduction}

Reconstruction of the last few centuries of climate in Iceland, often termed as the later part of the Little Ice Age (but see Ogilvie and Jónsson, 2001 for a critical review of the term and its Icelandic context), has relied largely on glacial histories (Stötter et al., 1999; Kirkbride and Dugmore, 2006; Geirsdóttir et al., 2009a), sea ice records interpreted from documentary sources (Ogilvie, 1984; Ogilvie, 2005), and palaeolimnological data (Axford et al., 2007, 2009; Geirsdóttir et al., 2009b). These records are however of variable temporal resolution and have tended to provide relatively poorly constrained proxy climate data. The lakes examined so far have been from relatively low altitudes and not shown the amplitude of terrestrial temperature variations recorded in the observational record over the last 160 years. Lakes in mountainous environments can be considered more sensitive to climate change, being the first sites to respond to warming/cooling in terms of species replacements as taxa living there are often at the limits of their tolerance. For example, if cold stenotherms are present at the site, and local

\footnotetext{
* Corresponding author.

E-mail address: p.g.langdon@soton.ac.uk (P.G. Langdon).
}

warming occurs, there are no places for the taxa to move to, as further downslope is likely to be even warmer, based on lapse rates, and if the lake is towards the top of the altitudinal range in the region then they are likely to become extinct locally (Brooks, 2000).

Using biotic systems for reconstructing past environmental change, notably climate, does have its problems. Lake biota respond to a number of driving factors such as changes in nutrients, temperature, dissolved oxygen, food quantity and quality, and predator-prey relationships for example (Brooks, 2006; Brodersen and Quinlan, 2006; Langdon et al., 2006). Often many of these factors are closely correlated, meaning that separating them in the fossil record, in the form of reconstructions, can be difficult. Hence, it is vital to choose sites where changes in only a few significant parameters exist, such as sites with simple geology, simple food-webs, low nutrients and simple bathymetries but close enough to ecotonal boundaries so that climate changes will impact the fauna significantly. Mountain lakes can often provide such examples.

Lake biota are known to be responsive to changes in temperature (e.g. Battarbee, 2000), but these changes are far more likely to be significant in mountain sites of high altitude and/or high latitude, where taxa are able to exist only at or around the edge of their thermal ranges. One biotic group that appears particularly sensitive to temperature changes are Chironomidae (non-biting midges). 
Space-for-time calibrations have been produced that show them to respond significantly to changes in mean summer temperatures (e.g. Larocque et al., 2001; Barley et al., 2006; Langdon et al., 2008) and these calibration approaches have been validated by comparisons with instrumental data (Larocque and Hall, 2003; Larocque et al., 2009). These studies notwithstanding, there have been few convincing quantitative reconstructions of LIA climate using chironomids. Brooks and Birks (2004) studied three lakes in Svalbard with sediment cores that covered the last 700 years. They did note a response in the changes in chironomid assemblages about 200 years ago, but no quantitative reconstructions were undertaken. Luoto et al. (2008) showed that there were clear changes in chironomid faunas from a site in Southern Finland over recent centuries which may have represented a LIA-type response. Luoto et al. (2009) added a quantitative reconstruction to the same site which did show a particularly cool phase to the LIA around AD 1700, albeit during a period when the lake was also likely responding to changes in trophic state as identified through diatom analyses. A study by Heiri et al. (2003) found that the chironomid record from the late Holocene was compromised by recent human activity, and hence they could not reconstruct temperatures from this period. The study by Langdon et al. (2004) did show some faunal changes associated with cooler temperatures during the LIA such as a first appearance of the cold stenotherm Heterotrissocladius grimshawi which was absent from the entire stratigraphy covering the previous 6000 years, but other changes also occurred at this time that may have been linked with altered substrates which impacted on the climate reconstruction.

Instrumental data exist for the latter part $\left(\sim 19^{\text {th }}\right.$ century $)$ of the LIA that suggest climates of individual years were up to ca. $2^{\circ} \mathrm{C}$ cooler than their 30 year averages, and periods lasting decades may have been on average ca. $1^{\circ} \mathrm{C}$ cooler (e.g. Stykkishólmur record in Iceland - http:// www.vedur.is, and the Central England Temperature time series Parker et al., 1992). We know little detail though of the climates before this period, and specifically how much colder, or not, they were compared with $20^{\text {th }}$ century climates. It is likely that the climate changes of the LIA, together with warming during the Medieval Climate Anomaly (MCA), were the greatest climate changes during the late Holocene, although we still know relatively little regarding the precise timing, magnitude and duration of peak warmth and cold times. It is the aim of this paper to address some of these issues by producing a quantitative summer temperature reconstruction from a high altitude lake sediment record for NW Iceland for the past 350 years.

\section{Methods}

Myfluguvatn (N 65은 47.703 , W $22^{\circ}$ 49.742) is a relatively highaltitude lake for NW Iceland ( $435 \mathrm{~m}$ a.s.l.) situated in the region that held the former Glama icecap (Fig. 1). The lake is relatively shallow $\left(z_{\max }=5.5 \mathrm{~m}\right)$ with clear water (secchi depth extended to the bottom) and consists of three main basins. It is situated on basalt and has similar limnological characteristics to other highland lakes $(>400$ $m$ a.s.l.) from NW Iceland, with no obvious human impact, that were documented by Langdon et al. (2008). Water quality measurements taken in August 2007 found conductivity to be $26 \mu \mathrm{S} / \mathrm{cm}, \mathrm{pH} 7.24$, low levels of chlorophyll $a(0.4 \mu \mathrm{g} / \mathrm{L})$ and high levels of dissolved oxygen $(12.06 \mathrm{mg} / \mathrm{L})$. The catchment is dominated by bare rock with some patches of thin soils with grass/moss vegetation. Replicate gravity cores were taken from the deepest point ( $5.5 \mathrm{~m}$ water depth) in the southern part of the lake (Fig. 1) in summer 2007 measuring $25 \mathrm{~cm}$ : MYF1 was extruded in the field and sliced into $1 \mathrm{~cm}$ subsamples, whereas MYF2 was capped and brought back to the laboratory intact in its core tube. The sediments were mainly composed of silty gyttja and a visible tephra layer was present at approximately $22.5 \mathrm{~cm}$ depth.
Contiguous subsamples were taken from MYF1 for chironomid analyses. Sediment was warmed in $10 \% \mathrm{KOH}$ and sieved following the methods outlined in Brooks et al. (2007). Chironomid head capsules were then picked from the samples and mounted on microscope slides in Hydromatrix ${ }^{\circledR}$. Identification and taxonomy followed Brooks et al. (2007). The subsamples were also analysed for percentage loss-on-ignition (\% LOI) following standard methods (Dean, 1974).

Statistical analyses of the chironomid data were undertaken through ordination analyses and application of a summer temperature transfer function developed by Langdon et al. (2008). The best transfer function model is based on a 51-lake data set and has optimum performance with a two component WA-PLS model with $r_{\text {jack }}^{2}=0.66, \operatorname{RMSEP}=1.095^{\circ} \mathrm{C}$ and maximum bias $1.097^{\circ} \mathrm{C}$. The model has been used previously to reconstruct early to mid-Holocene climates in Iceland (Caseldine et al., 2006; Axford et al., 2007; Langdon et al., 2008) but this is the first time it has been used to validate chironomid inferred summer temperatures (CI-T) against instrumental data. All taxa present within the fossil data set are present in the training set, although as Oliveridia only occurs in one lake within the training set, this site (and taxon) occur as an outlier and are not present in the final model (Langdon et al., 2008). The fact that the model used does not contain Oliveridia, a cold stenotherm (Brooks et al., 2007), may mean that the CI-T during phases of Oliveridia abundance are underestimates (Axford et al., 2007). In modern chironomid communities in Iceland Oliveridia often co-occurs with Pseudodiamesa, and their temperature optima are similar (Langdon et al., 2008). In order to test the effect of not modelling the response of Oliveridia in the Myfluguvatn core we compared the modelled results shown below (with no Oliveridia) with another model run where the Oliveridia fossil percentage abundance data were combined with Pseudodiamesa, as the ecological and temperature optima of these taxa are similar. The result of this latter model run are almost identical in terms of trends to the CI-T data presented in the paper (with no Oliveridia) but are slightly cooler $\left(0.6-0.3^{\circ} \mathrm{C}\right.$ ) during phases of high abundances of Oliveridia, as expected. CANOCO 4.5.2 (ter Braak and Smilauer, 1998) was used for detrended correspondence analysis (DCA) in order to determine the main environmental controls on the chironomid assemblages and C2 (Juggins, 2003) was used for the transfer function analyses. All analyses involved square root transforming the species data and down-weighting of rare types.

The MYF2 sediment core was split in half back in the laboratory, and analysed using the Itrax micro-XRF core scanner (Croudace et al., 2006) at the British Ocean Sediment Core Research Facility (National Oceanography Centre, Southampton). This provided high-resolution, down-core elemental compositional variations and X-radiographic images (positives) at resolutions of $200 \mu \mathrm{m}$, or a little over 3 months of sediment accumulation based on the dating model (see below).

\section{Geochronology}

\section{Tephra}

Field stratigraphy (MYF1) and geochemical analysis using Itrax (MYF2) identified one major tephra layer that has been analysed from the Myfluguvatn core. This sample was treated by a density separation technique in order to concentrate the silicic glass component (Turney, 1998) and the density fraction between 2.3 and $2.5 \mathrm{~g} / \mathrm{cm}^{3}$ was chosen for geochemical analysis. Most analysed shards have a rhyolitic composition with $\mathrm{SiO}_{2}$ values between 68 and $70 \%$ (Fig. 2) and $\mathrm{K}_{2} \mathrm{O}$ and $\mathrm{FeO}_{\text {tot }}$ concentrations around 3.7 and $2.9 \%$, respectively. Eight of the analysed particles show a tight cluster in plots of e.g. $\mathrm{FeO}_{\mathrm{tot}} / \mathrm{TiO}_{2}$ (Fig. 3). One particle has an andesitic composition with a $\mathrm{SiO}_{2}$ and $\mathrm{MgO}$ concentrations of $59.4 \%$ and $1.9 \%$, respectively. However, comparisons with published data of historical tephras do not permit a secure correlation of the main population with any known tephra layer in Iceland or in distal 


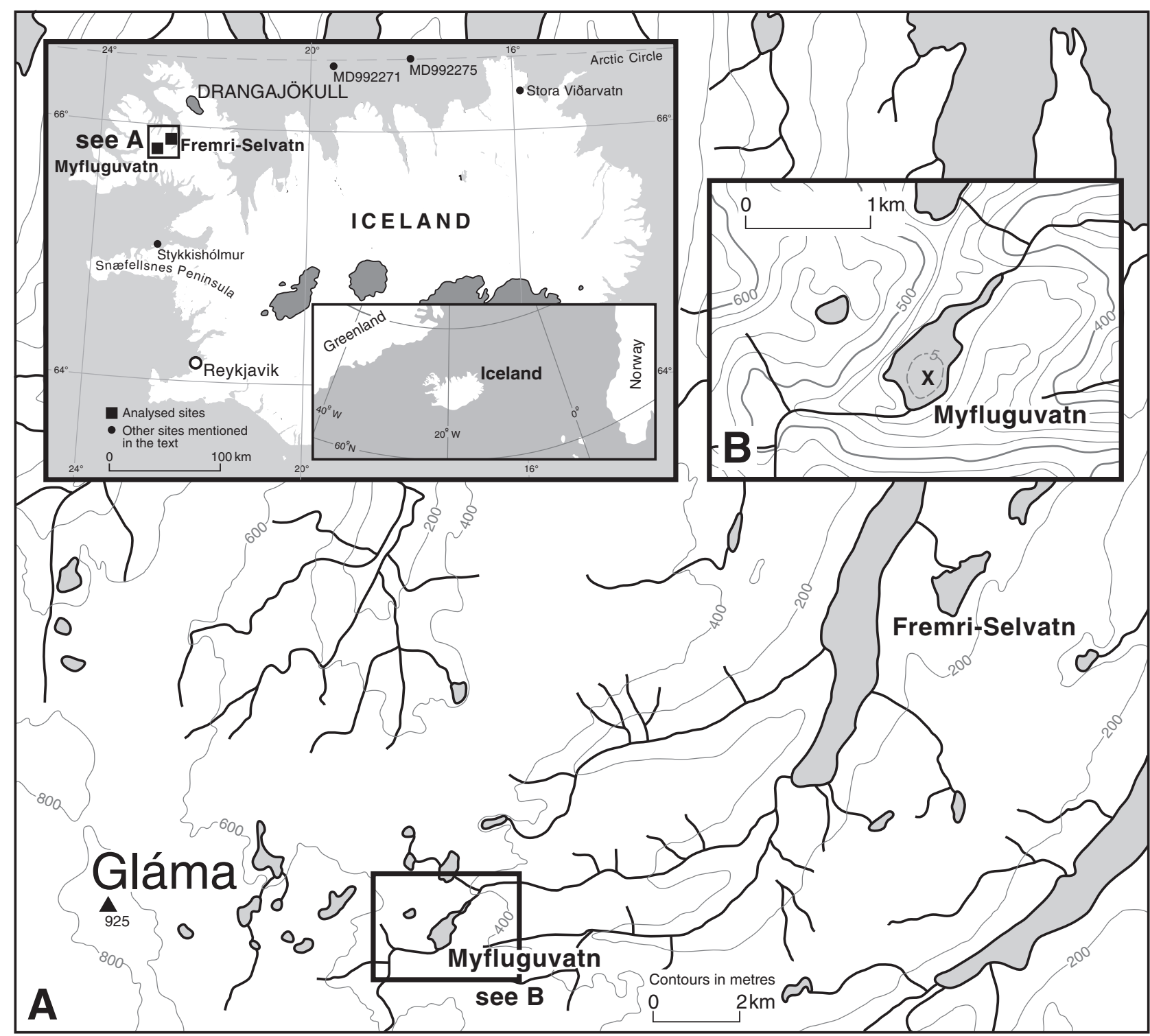

Figure 1. Map showing the detailed location of Myfluguvatn including the coring site, and other sites mentioned in the text. Inset B shows the simplified bathymetry of the lake.

areas (e.g. Larsen et al., 1999; Wastegård and Davies, 2009). Historical tephras with $\mathrm{SiO}_{2}$ concentrations in the range of $68-70 \%$ are few and Hekla-1104, Hekla-1158. Öræfajökull -1362 and Askja1875 are the only eruptions with such high $\mathrm{SiO}_{2}$ concentrations ( $\mathrm{G}$. Larsen, personal communication, 2008).

In a TAS diagram (Fig. 2) most analyses plot marginally outside the compositional range of Holocene tephras from the Hekla volcano (e.g. Wastegård and Davies, 2009). More evolved volcanic centres such as Snæfellsnes and Torfajökull can probably be excluded as sources for the Myfluguvatn tephra, even if reworking of tephra from the drainage area is considered. The Myfluguvatn tephra has some similarities with the silicic component of the Landnám tephra (source Torfajökull, AD 870s; Table 1), but is distinctly lower in $\mathrm{K}_{2} \mathrm{O}$ and higher in $\mathrm{FeO}_{\text {tot }}$ and $\mathrm{CaO}$. Lower $\mathrm{FeO}_{\text {tot }}, \mathrm{Al}_{2} \mathrm{O}_{3}$ and $\mathrm{K}_{2} \mathrm{O}$ distinguish the Myfluguvatn tephra from the $\mathrm{Sn}-1$ tephra (source: Snæfellsnes, AD 100-200s; Table 1). The $\mathrm{SiO}_{2}$ vs. alkali content follow the evolutionary trend of the Öræfajökull volcanic system (eruptions in AD 1362 and 1727), but the agreement with other oxides (e.g. $\mathrm{Al}_{2} \mathrm{O}_{3}$ and $\mathrm{Na}_{2} \mathrm{O}$ ) is less good (Table 1).

Tephra from the eruption of Hekla in 1693 was recently found in the nearby lake Fremri-Selvatn, ca $15 \mathrm{~km}$ from Lake Myfluguvatn
(Fig. 1; Table 1). Hekla-1693 has not been confirmed in northwest Iceland before, but the main axis of distribution to NW indicates that this is possible (Larsen et al., 1999, Fig. 2). One particle of the Myfluguvatn tephra can be correlated with the Hekla-1693 tephra (Dugmore et al., 2007) and it is possible that the density separation technique has concentrated only the most rhyolitic particles from the earliest part of the eruption. In many other Hekla tephra layers, where the $\mathrm{SiO}_{2}$ of the main population is $63 \%$ or lower, the earliest erupted tephra contains a sprinkle of grains with much higher silica, e.g. $\mathrm{SiO}_{2}$ 68-72\% and sometimes the $\mathrm{K}_{2} \mathrm{O}$ concentrations in these grains can be up to 4-5\% (Dugmore et al., 1995; Larsen et al., 1999; G. Larsen, personal communication, 2008). Based on the geochemical composition we suggest that the Myfluguvatn tephra originates from the Hekla volcanic system and the main axis of distribution towards NW (Larsen et al., 1999), the occurrence of the Hekla-1693 tephra in Fremri-Selvatn and the independent $\mathrm{Pb}-210$ chronology (see below) make a correlation with Hekla-1693 most likely. Hekla1636 and 1766 do not match the geochemical composition of the Myfluguvatn tephra (G. Larsen, pers. comm., 2009) and the distribution towards NE and N, respectively (Larsen et al., 1999), make these tephras less likely candidates. 


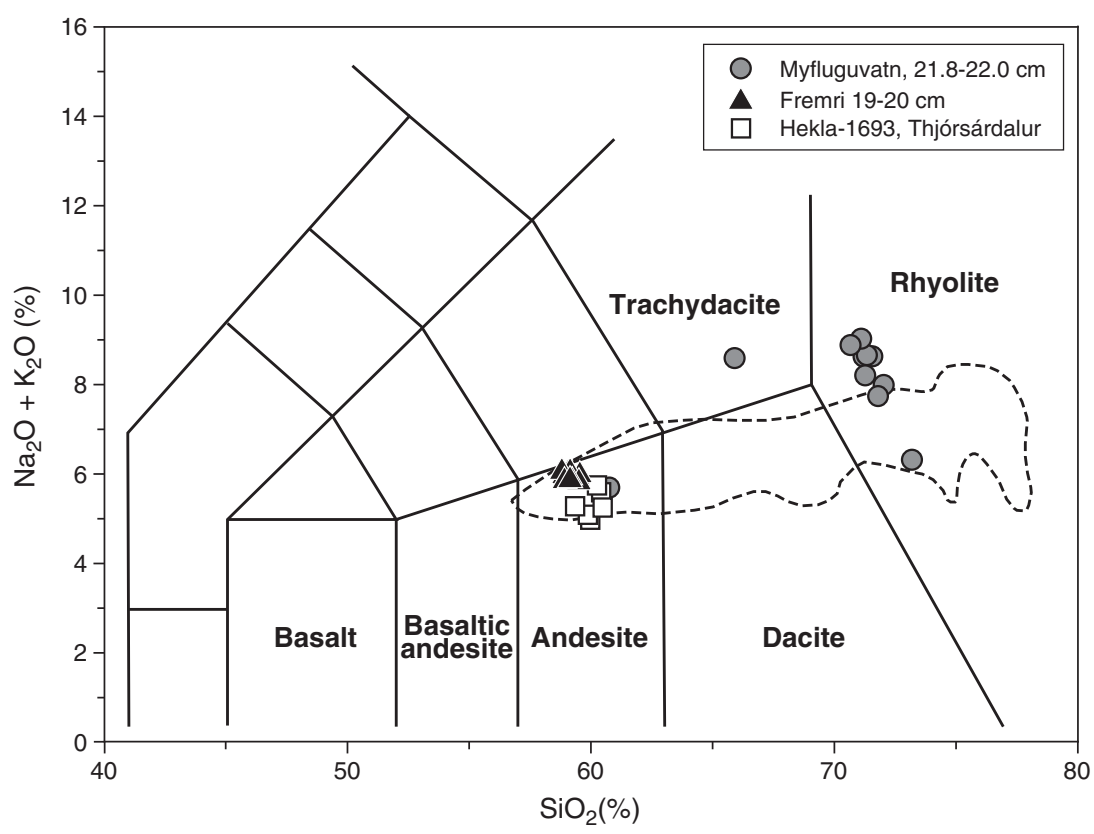

Figure 2. TAS plot of the tephra layer from Myfluguvatn and Hekla-1693 from Thjórsárdalur (Dugmore et al., 2007) and Fremri-Selvatn (Langdon et al., unpublished). The dashed area shows the distribution of all published tephras from Hekla (data from tephrabase; www.tephrabase.org).

\section{Pb-210, Cs-137 and a dating model}

A multi-proxy approach was used for dating, primarily based on a constant initial concentration - constant rate of sedimentation (CIC-CRS; Robbins, 1978) Pb-210 dating model. This is verified by identification of the 1963 peak in Cs-137 and refined using an identified tephra (Hekla-1693; see above). The core sampled in the field at $1 \mathrm{~cm}$ intervals (MYF1) was used for sediment dating purposes.

$\mathrm{Pb}-210$ activities of the samples were determined via the proxy method using alpha spectrometric determination of Po-210 activity (Flynn, 1968). One gram of each sample was spiked with Po-209 to monitor the chemical yield. The sample was digested using a double aqua regia attack and Po separated by auto-deposition onto a freshly cleaned silver disc. The Po-210 activity was then determined by alpha spectrometry. The total $\mathrm{Pb}-210$ activity profile is illustrated in Figure 4b. Supported (equilibrium) Pb-210 activity was estimated by observing activity in the deepest samples where the excess $\mathrm{Pb}-210$ activity tended towards zero and was determined to be $0.0040 \pm 0.0002$ $\mathrm{Bq} / \mathrm{g}$. A linear fit through a plot of the natural logarithm of the determined excess $\mathrm{Pb}-210$ activities for each sample (Fig. 4c) yielded an average accumulation rate for the sediment of $0.077 \pm 0.008 \mathrm{~cm} /$ year. It was observed that there were some deviations from the linear fit, particularly near to the top of the sediment. Given this, a variable sedimentation rate model (using the constant rate of supply assumption, Appleby and Oldfield, 1978) was developed but showed that deviations from an averaged linear accumulation rate were localised and minimal.

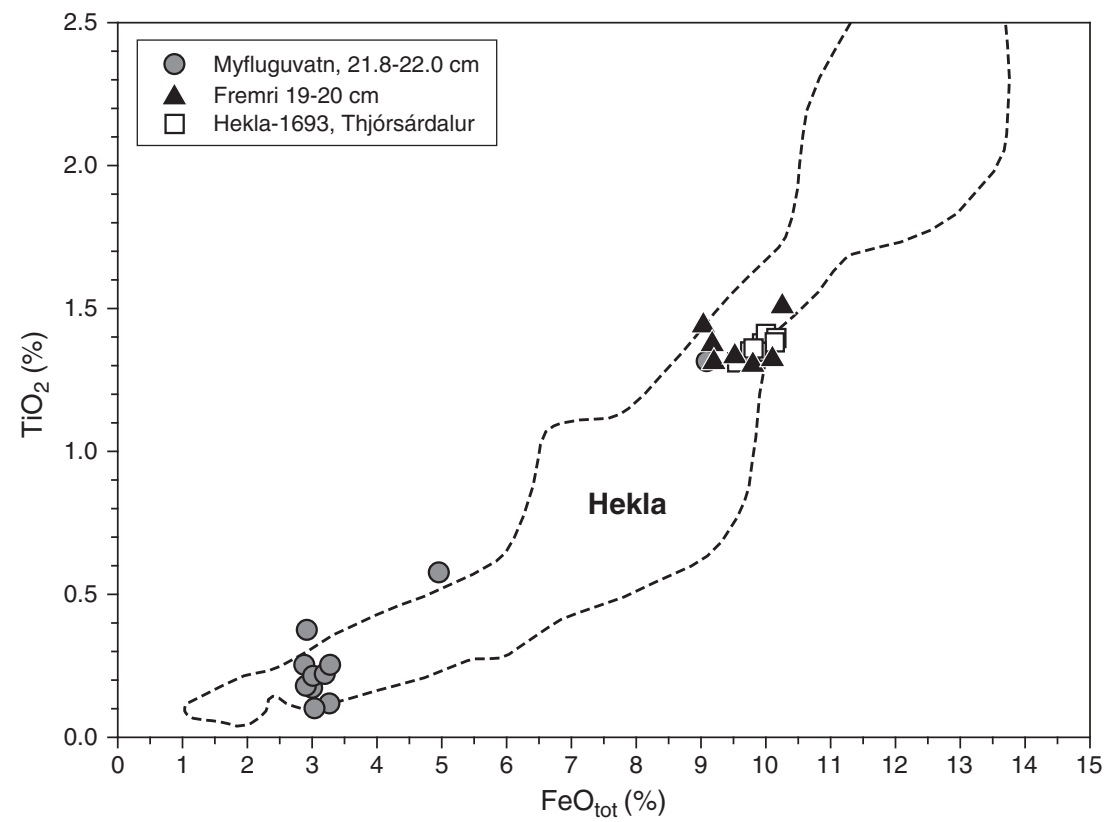

Figure 3. $\mathrm{FeO}_{\text {tot }} / \mathrm{TiO}_{2}$ plot of the tephra layer from Myfluguvatn and Hekla-1693 from Thjórsárdalur (Dugmore et al., 2007) and Fremri-Selvatn (Langdon et al., unpublished). The dashed areas show the distribution of all published tephras from Hekla (data from tephrabase; www.tephrabase.org). All analyses have been normalised to 100\%. 
Table 1

Geochemistry of the tephra layer at 21.8-22.0 cm in Myfluguvatn, determined by electron microprobe analyses. The samples were analysed with a Cameca SX100 electron microprobe equipped with 5 vertical WD Spectrometers. Ten major elements were measured with a counting time of $10 \mathrm{~s}$. An accelerating voltage of $10 \mathrm{kV}$, a beam strength of $4 \mathrm{nA}$ and $5 \mu \mathrm{m}$ beam diameter was used. Only analyses $>94$ wt.\% are listed. The geochemistry of the Hekla-1693 from Thjórsárdalur (Dugmore et al., 2007) and Fremri-Selvatn (Langdon et al., unpublished) is shown for comparison. Mean values of the silicic part of the Landnám tephra (AD 870s; Wastegård et al., 2003), the Sn-1 tephra (AD 100-200s; Larsen et al., 2002) and Oerafajökull-1362 and 1727 (0-1362 and 0-1727; Larsen et al., 1999) are also listed. *Not included in mean.

\begin{tabular}{|c|c|c|c|c|c|c|c|c|c|c|c|c|c|}
\hline & $\mathrm{SiO}_{2}$ & $\mathrm{TiO}_{2}$ & $\mathrm{Al}_{2} \mathrm{O}_{3}$ & $\mathrm{FeO}_{\text {tot }}$ & Mno & Mg0 & $\mathrm{CaO}$ & $\mathrm{Na}_{2} \mathrm{O}$ & $\mathbf{K}_{2} \mathbf{O}$ & $\mathbf{P}_{2} \mathbf{O}_{5}$ & Cl & Total & Correlation \\
\hline \multirow[t]{9}{*}{ Myfluguvatn $21.8-22.0 \mathrm{~cm}\left(2.3-2.5 \mathrm{~g} / \mathrm{cm}^{3}\right)$} & 70.07 & 0.10 & 14.76 & 2.99 & 0.22 & 0.10 & 1.18 & 4.61 & 3.93 & 0.15 & 0.27 & 98.39 & Hekla-1693 \\
\hline & 69.49 & 0.17 & 14.31 & 2.89 & 0.15 & 0.09 & 1.15 & 4.47 & 3.38 & 0.07 & 0.30 & 96.46 & Hekla-1693 \\
\hline & 69.47 & 0.24 & 14.37 & 2.82 & 0.20 & 0.08 & 1.04 & 4.64 & 3.85 & 0.07 & 0.28 & 97.07 & Hekla-1693 \\
\hline & 69.44 & 0.21 & 14.47 & 2.94 & 0.13 & 0.10 & 1.20 & 4.55 & 3.98 & 0.03 & 0.29 & 97.33 & Hekla-1693 \\
\hline & 68.86 & 0.18 & 14.15 & 2.82 & 0.19 & 0.13 & 1.24 & 4.64 & 4.22 & 0.09 & 0.31 & 96.83 & Hekla-1693 \\
\hline & 68.73 & 0.21 & 14.69 & 3.12 & 0.09 & 0.12 & 1.19 & 4.64 & 4.10 & 0.07 & 0.29 & 97.24 & Hekla-1693 \\
\hline & 68.06 & 0.35 & 14.29 & 2.77 & 0.15 & 0.09 & 1.15 & 4.54 & 3.01 & 0.06 & 0.29 & 94.87 & Hekla-1693 \\
\hline & 67.15 & 0.11 & 14.19 & 3.08 & 0.02 & 0.12 & 1.20 & 4.36 & 3.60 & 0.05 & 0.32 & 94.20 & Hekla-1693 \\
\hline & 59.38 & 1.28 & 14.67 & 8.90 & 0.23 & 1.86 & 5.16 & 3.98 & 1.65 & 0.56 & 0.04 & 97.72 & Hekla-1693* \\
\hline Mean $(n=8)$ : & 68.91 & 0.20 & 14.41 & 2.93 & 0.14 & 0.10 & 1.17 & 4.56 & 3.76 & 0.07 & 0.30 & 96.54 & \\
\hline \multirow[t]{3}{*}{$1 \sigma$} & 0.94 & 0.08 & 0.22 & 0.13 & 0.07 & 0.02 & 0.06 & 0.10 & 0.40 & 0.04 & 0.02 & & \\
\hline & 69.73 & 0.24 & 13.31 & 3.12 & 0.08 & 0.12 & 2.04 & 3.80 & 2.37 & 0.34 & 0.10 & 95.26 & outlier \\
\hline & 64.10 & 0.56 & 15.45 & 4.82 & 0.25 & 0.50 & 2.48 & 4.85 & 3.62 & 0.31 & 0.31 & 97.24 & outlier \\
\hline Fremri, $19-20 \mathrm{~cm}$, mean $(n=7)$ & 58.64 & 1.34 & 14.97 & 9.33 & 0.28 & 1.91 & 5.48 & 3.36 & 1.50 & 0.53 & & 97.40 & Hekla-1693 \\
\hline $1 \sigma$ & 0.75 & 0.06 & 0.29 & 0.47 & 0.06 & 0.19 & 0.15 & 1.05 & 0.12 & 0.06 & & & \\
\hline H-1693, Thjórsárdalur ( $n=10)$ & 58.12 & 1.34 & 15.06 & 9.75 & 0.28 & 1.94 & 5.35 & 4.40 & 1.54 & 0.56 & & 98.33 & Hekla-1693 \\
\hline $1 \sigma$ & 0.32 & 0.03 & 0.10 & 0.18 & 0.03 & 0.03 & 0.06 & 0.08 & 0.04 & 0.02 & & & \\
\hline Landnám, Ásólfsstadir ( $n=8$ ) & 70.26 & 0.30 & 14.31 & 2.45 & 0.07 & 0.27 & 0.92 & 4.42 & 4.52 & n.a. & & 97.52 & Landnám (sil.) \\
\hline $1 \sigma$ & 0.76 & 0.03 & 0.24 & 0.13 & 0.02 & 0.02 & 0.06 & 0.32 & 0.11 & & & & \\
\hline Sn-1, Snaefellsnes $(n=6)$ & 67.27 & 0.38 & 15.66 & 4.08 & n.a. & 0.33 & 1.72 & 5.07 & 4.36 & 0.07 & & 98.96 & Sn-1 \\
\hline $1 \sigma$ & 1.21 & 0.04 & 0.37 & 0.40 & & 0.12 & 0.35 & 0.19 & 0.23 & 0.09 & & & \\
\hline 0-1362. Svinafell $(n=8)$ & 71.36 & 0.22 & 13.14 & 3.12 & 0.10 & 0.03 & 0.98 & 5.55 & 3.38 & n.a. & & 97.89 & $0-1362$ \\
\hline $1 \sigma$ & 0.69 & 0.02 & 0.26 & 0.09 & 0.03 & 0.02 & 0.06 & 0.14 & 0.12 & & & & \\
\hline $0-1727$, Svinafell $(n=19)$ & 57.92 & 1.62 & 13.65 & 12.71 & 0.37 & 1.37 & 5.21 & 4.42 & 1.63 & & & 98.88 & $0-1727$ \\
\hline $1 \sigma$ & 0.66 & 0.14 & 0.46 & 0.57 & 0.05 & 0.13 & 0.16 & 0.39 & 0.11 & & & & \\
\hline
\end{tabular}

Cs-137 activity was determined using a Canberra well-type HPGe gamma-ray spectrometer for the top $12 \mathrm{~cm}$ of samples and each activity was corrected for sample mass and volume. A peak in activity taken to correspond to the 1963 maximum (Ritchie and McHenry, 1990) was found at a depth of $3.4 \pm 0.1 \mathrm{~cm}$ in the Cs-137 profile (Fig. 4a), suggesting an average sediment accumulation rate from 1963 to the sampling date of $0.07 \pm 0.03 \mathrm{~cm} /$ year (the relatively low accumulation rate and uncertainty in the peak and sampling positions contribute to the relatively large uncertainty in this value). This sedimentation rate is consistent with that determined using solely
$\mathrm{Pb}-210$ activities. There is a tephra at approximately $22.5 \mathrm{~cm}$ depth (high density region indicated by low x-ray transmission at $22.5 \mathrm{~cm}$, Fig. 4d). Based on its chemistry (see above) and position (between AD 1680 and $\mathrm{AD} 1742$ from lead dating) the tephra is identified as most likely Hekla-1693. Placing 1693 at $22.5 \mathrm{~cm}$ deep in the core implies an average sedimentation rate of $0.072 \pm 0.004 \mathrm{~cm} /$ year. Caesium, lead and tephra inferred mean accumulation rates are therefore $0.07 \pm$ $0.03,0.077 \pm 0.008$ and $0.072 \pm 0.004 \mathrm{~cm} /$ year, respectively. We have used the most precise (tephra inferred) sedimentation rate for dating the core.

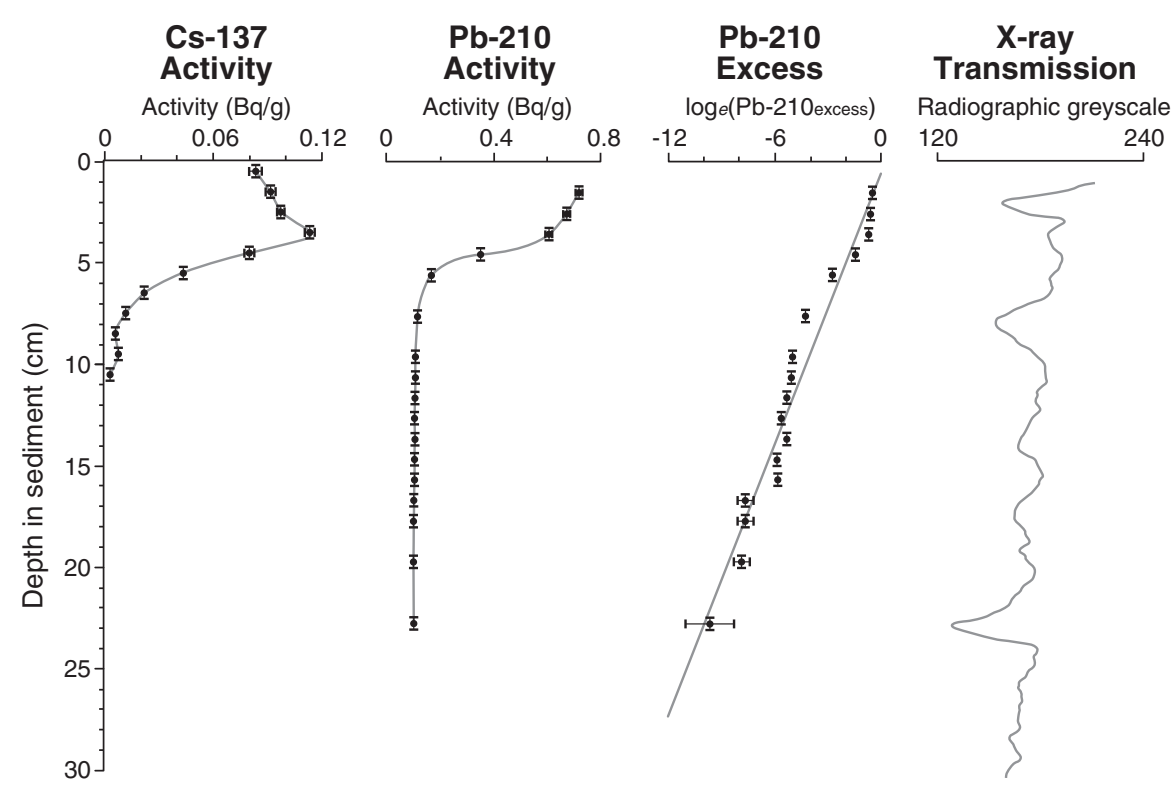

Figure 4. Development of a dating model. (a) Cs-137 activity. (b) Total inferred Pb-210 activity profile. (c) Natural log of Pb-210 excess. (d) X-ray transmission (represented as greyscale values from the Itrax radiographic image: higher values imply lower density). X-ray transmission is from the Itrax MYF2 core, activities are from MYF1. 
Results

\section{Chironomidae}

In total 21 chironomid taxa were identified from 25 contiguous $\mathrm{cm}$ samples from MYF1 (Fig. 5). The samples are dominated by Micropsectra spp, typically a cold stenotherm in Icelandic lakes which shows a significant relationship with low mean July air temperature $(p<0.005)$ (Langdon et al., 2008). Three Micropsectra species have been recorded from Icelandic lakes; M. atrofasciata, $M$. recurvata and $M$. lindrothi (Hrafnsdóttir, 2005), although as reported in Langdon et al. (2008), in the absence of reared larvae it was difficult to split the subfossil head capsules into these three species. Hence Micropsectra individuals were lumped into genus only in both the training set (Langdon et al., 2008) and fossil reconstruction from Myfluguvatn. While it is not uncommon for a single taxon to dominate lakes at high altitudes/latitudes (e.g. Brooks and Birks, 2004), major changes in biostratigraphy do occur when sites are located at altitudes that allow taxa with clear warm/cold optima to migrate up/down to the site depending on changing climate. This is shown at Myfluguvatn, as other taxa oscillate throughout the profile, notably Diamesa spp and Eukiefferiella fittkaui-type. Significant changes in the chironomid stratigraphy occur between 10 and $6 \mathrm{~cm}$ depth (AD 1876-1917 based on the age model, with a maximum error of 8 years), in which \% abundance of Pseudodiamesa and Oliveridia increase considerably. An increase in \% abundance is also noted in Corynoneura arctica-type during this period, although the rise is less significant than in the other two taxa. Following this change in fauna the chironomids do not revert back to the previous \% abundances, but rather there is a general reduction in \% abundance of Micropsectra, with relative increases in \% abundance of Heterotrissocladius grimshawi-type and Orthocladius type I from $6 \mathrm{~cm}$ to the top of the core (AD 1917 to 2007). The chironomid sequence would appear to contain many rheophiles, and while the lake is an open system with small inflows to the west, Lindegaard (1992) has shown that many rheophilic taxa, especially Diamesa spp. can be found in the surf zone of Icelandic lakes.
A chironomid inferred summer air temperature (CI-T) reconstruction was undertaken on the MYF1 data set using an Icelandic training set developed by Langdon et al. (2008) (Fig. 6). The MYF1 reconstructed temperatures range from 8.5 to $5.3^{\circ} \mathrm{C}$ over the period from $\mathrm{AD} 1670$ to present. The uppermost sample reconstructed a mean July air temperature of $7.3^{\circ} \mathrm{C}$ which is in accordance with the modern value, based on the $1961-90$ average, of $7.1^{\circ} \mathrm{C}$. The consistently coolest reconstructed temperatures are recorded between AD 1890 and 1917 and represent the stratigraphic phase which is dominated by the coldest stenotherms: Pseudodiamesa and Oliveridia. These reconstructed temperatures represent a drop of $\sim 1.65^{\circ} \mathrm{C}$ from the mean temperature $\left(6.95^{\circ} \mathrm{C}\right)$ recorded throughout the period of study and reconstructed temperatures $\sim 1.8^{\circ} \mathrm{C}$ cooler than modern July temperatures at the site. Equally large drops in temperature, as recorded by relatively consistently cool phases identified in 2 or more consecutive samples, occur between AD 1683-1710 and AD 1765-1780 (Fig. 6). The DCA axis 1 scores (Fig. 6) reflect species turnover throughout the profile and show a significant oscillation, in terms of departures from the norm, between AD 1876 and 1917. The overall pattern of change is similar to that seen in the CI-T reconstruction, giving added confidence that the changes in taxa through time are likely representative of changes in temperature, and that the trends within the CI-T reconstruction are robust. The LOI data are also plotted in Figure 6, and show relatively little change throughout the profile until post AD 1950, when organic content increases by $50 \%$ and continues this trend until present.

\section{Lake sediment chemistry}

The Itrax elemental profiles, radiographic image and independently determined LOI data are presented in Figure 7. In general, the elemental profiles show a lake catchment that has been very stable over the period of sediment accumulation, with little variation in the absolute or relative levels of the characteristic elements present. Significant deviations from this stability are present around AD 1693, corresponding to tephra input from a Hekla eruption which geochemical evidence suggests is of that year (see geochronology section). An increase in density of the sediment at this point is also apparent from a dark band on the radiograph.

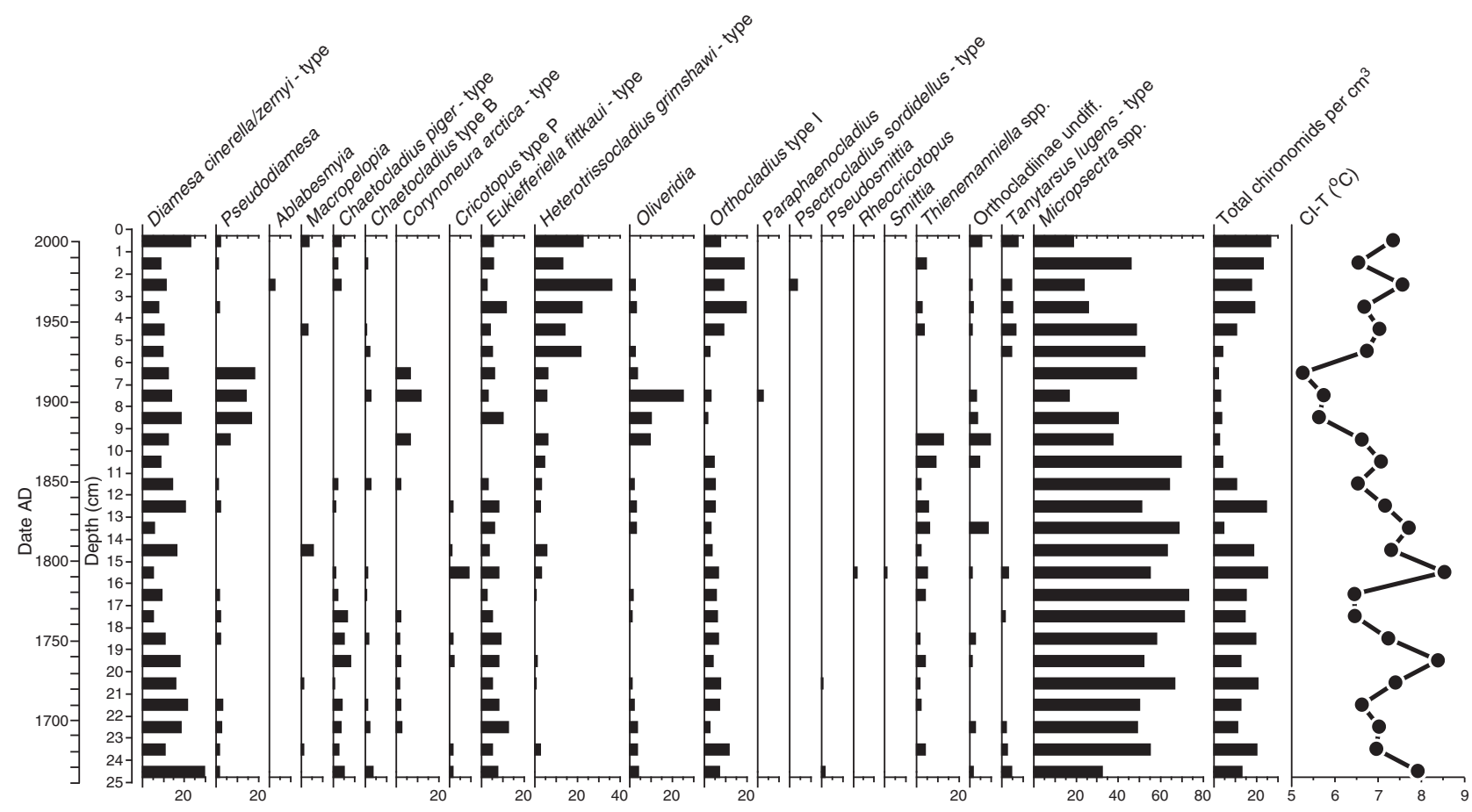

Figure 5. Chironomid stratigraphy showing all recorded taxa in percentage abundances and the CI-T reconstruction. Taxonomy follows Brooks et al. (2007). 


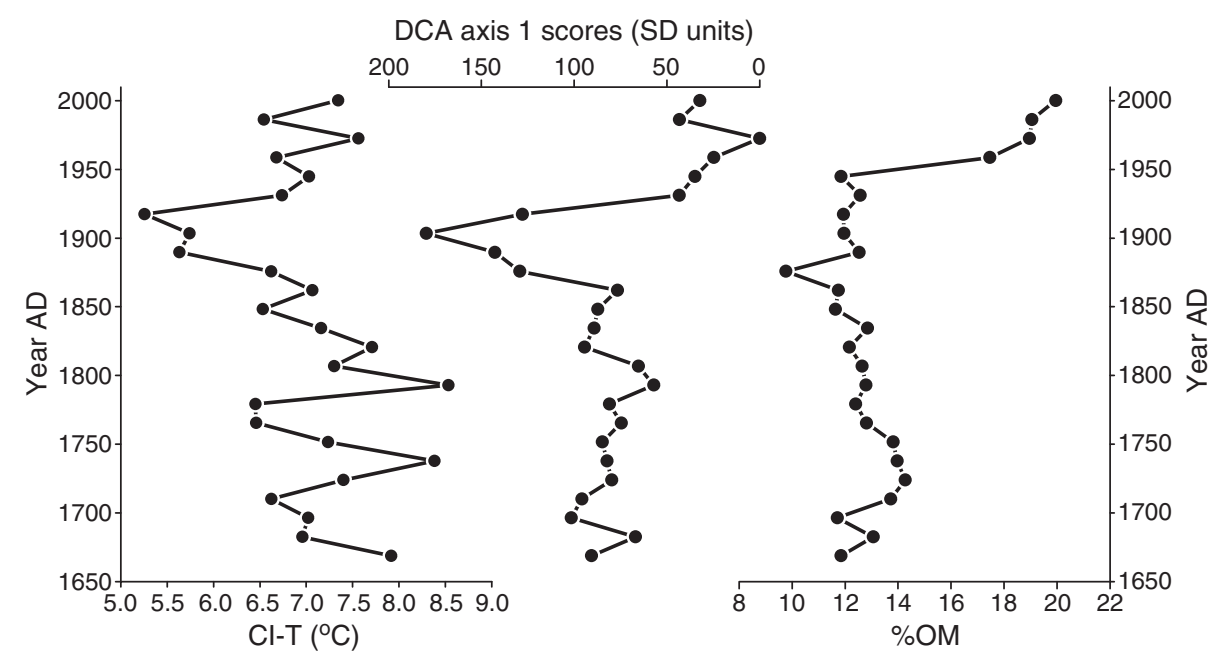

Figure 6. Comparative plots showing the CI-T, DCA axis 1 scores (x100) and LOI records against the same age model.

Smaller deviations occur around AD 1750, likely to be due to input of tephra from the 1766 eruption of Hekla (consistent within the dating uncertainty at this point), although no geochemical analyses were undertaken on any shards associated with this potential ash layer. The profiles also reveal a reduction in peak areas for elements associated with clastic input from the catchment over approximately the last 40 years. This corresponds to an increase in organic content as inferred from LOI and so could be representative of either increased productivity in the lake or catchment, or reduced catchment erosion or a combination of these. Alternatively it may simply be a result of differential preservation and/or diagenetic effects.

Present towards the top of the sediment, within the last twenty years, is a second dark band on the radiograph. This is associated with small increases in some of the clastic elements, notably strontium and zirconium, but does not exhibit deviations across the wide range of elements expected when a tephra is incorporated in to the sediment. This is therefore interpreted as an inwash event from within the catchment, leading to greater density of the sediment but little change in the relative levels of elements detectable by the Itrax core scanner.

\section{Discussion}

In order to assess the validity of the $\mathrm{CI}-\mathrm{T}$ reconstruction we have compared the data set with instrumental data from Iceland, including the Stykkishólmur air temperature record which extends back to AD 1823 as well as a Northern Iceland (NI) sea surface temperature (SST)

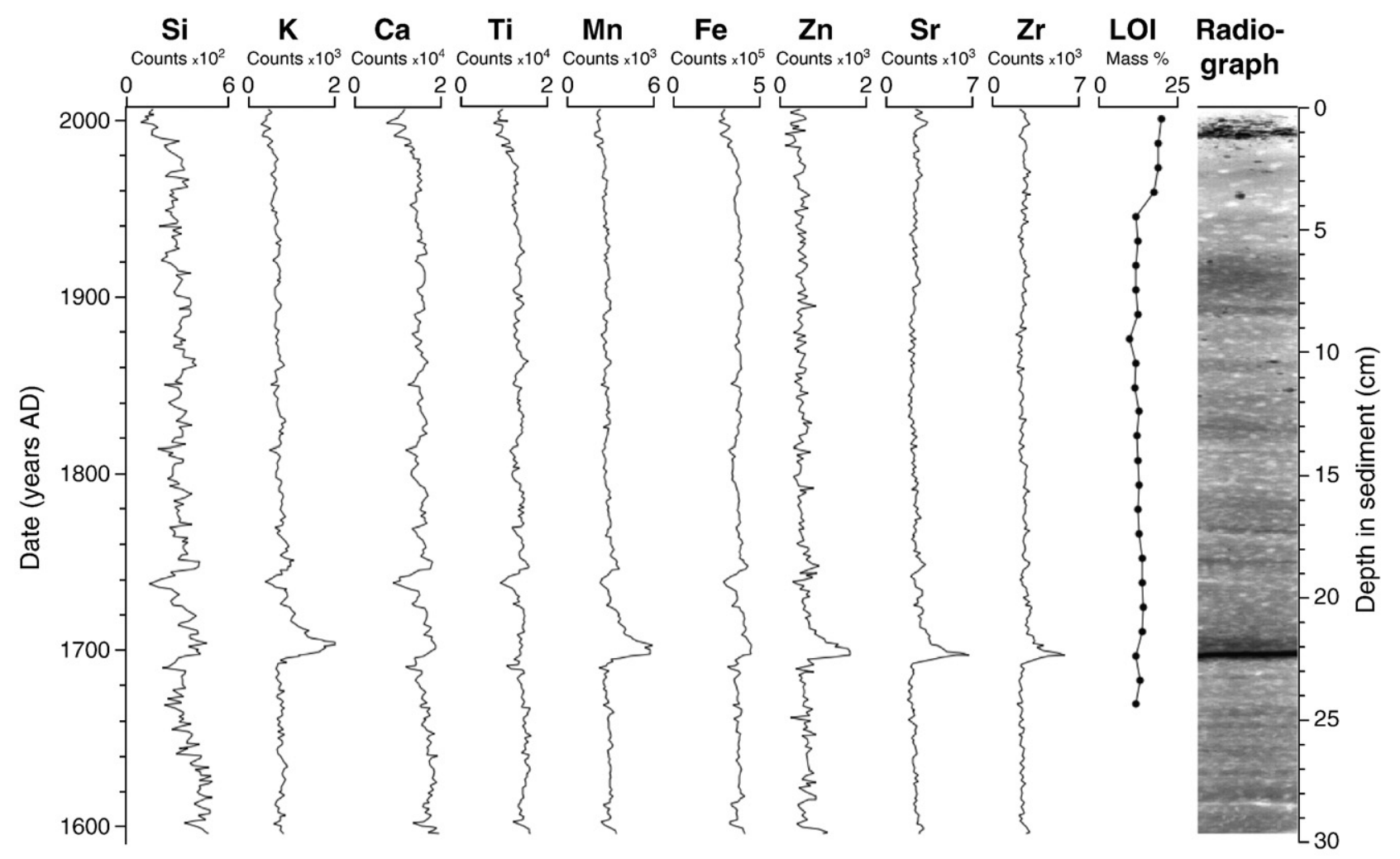

Figure 7. Plots showing the Itrax elemental data and X-ray radiographic image (from MYF2) compared with the LOI data (MYF1). Dates older than 1690 are speculative and assume the same average sedimentation rate observed for 1693 to present. 
record (Hanna et al., 2006) and a preliminary sea ice record (Ogilvie, 2005) (Fig. 8). The 119 year continuous NI SST record is compiled from regression analysis and splicing of three north coast stations: Grímsey, Hraun, and Raufarhöfn (Hanna et al., 2006). All measurements were made from land and include temperatures at beaches, below cliffs and inside harbours, but the considerable coherence between common periods at the three stations suggest reliability in the record (Hanna et al., 2006). The preliminary sea ice record is a compilation from sites around Iceland and is a mixture of observational and documentary data (Ogilvie, 2005). These instrumental records are annual in nature, whereas the main problem with the $\mathrm{Cl}-\mathrm{T}$ reconstruction is that the contiguous $\mathrm{cm}$ scale samples are resolved to one sample every ca. 14 years. This level of resolution does, however, preserve the low-frequency record, which is notoriously hard to achieve with annually resolved data sets such as treering records (Esper et al., 2002), but it means that the fossils from every 10-15 years are merged into one sample, making detailed comparisons with annually resolved data sets, such as the Stykkishólmur record, difficult. Nonetheless, in terms of the major trends there are clear correlations with the coldest phase in the Cl-T reconstruction between AD 1890 and 1917 and the SST composite record of Hanna et al. (2006), and good links with years of high sea ice (Ogilvie, 2005) (Fig. 8). Good correlations also exist between the CI-T data and Stykkishólmur temperature record, although there appears to either be a lag in the chironomid data set from the coldest phase in comparison with Stykkishólmur, or this phase in the CI-T is not recorded as being as cold. If we adjust the CI-T record to sea level using lapse rates and smooth the Stykkishólmur data to the same resolution as CI-T reconstruction, comparisons between the two time series in terms of absolute values is good, considering only 13 points are available for correlation (Pearson correlation coefficient is $0.46 ; p=0.1$ ). In summary we can be clear that the major trends compare well between our reconstruction and land temperature instrumental data such as Stykkishólmur and offshore SST/ sea ice records.

This finding is significant. Only twice previously have instrumental data sets been compared favourably with CI-T reconstructions (Larocque and Hall, 2003; Larocque et al., 2009) and this is the first time that such relationships have been confirmed outside mainland Europe. In general there have been few studies of recent changes in chironomid faunas in climatically sensitive regions at the decadal scale and with highly resolved chronologies. The use of transfer functions for reconstructing single environmental variables from biotic proxies (i.e. climate in this instance) has long been a matter of debate (see Korhola et al., 2001 and references therein). It is not enough to simply create transfer functions which have good predictive powers, the real proof is in model validation, for it is well recognised that species almost always respond to several interacting forces which may cascade down the food-web, leading to modelled species-environment relationships being often indirect (see Sayer et al., 2010 for a full discussion). It is our contention that where food-webs are relatively simple, for example in high latitude/altitude environments, clear relationships between the biota and a response to climate (often temperature) can be observed and we argue that our data help to illustrate this point. The relatively high altitude of Myfluguvatn (for Iceland) appears important as previous attempts to compare recent chironomid records with instrumental data, using lower altitude sites, have been less successful using transfer function approaches (Holmes, 2006; Axford et al., 2009). The Axford et al. (2009) study did show a strong correlation between chironomid assemblage shifts and temperatures, although the faunal changes observed in these lower altitude sites showed less species turnover during recent centuries than at Myfluguvatn, and it may be that at these relatively lower altitudes summer temperatures were simply not cold enough during this period for the cold stenotherms of the Icelandic fauna, such as Pseudodiamesa and Oliveridia, to colonise. This is an important point for determining what sites will be sensitive to climate change for chironomid studies.

Having demonstrated that the Myfluguvatn $\mathrm{CI}-\mathrm{T}$ record is a good indicator of temperatures over the last ca. 150 years, there is little reason to doubt the integrity of the record for the older part of the sequence. Two clear phases of relatively cooler temperatures exist within the CI-T reconstruction, between $\mathrm{AD}$ 1683-1710 and AD 1765-1780. Comparisons with other regional and wider records are difficult, due to the better dating precision of this reconstruction compared to the relatively poor chronological control that accompanies most other records for the same period from Iceland and other sub-Arctic locations within the North Atlantic. Nonetheless, some of the glacial records from Iceland do show remarkable consistency in comparison with the Myfluguvatn data set. Kirkbride and Dugmore (2006) reconstructed glacial advances in central Iceland to AD 1690-1740 and AD 1880-1920. Although the dating of these advances was hampered by a relative lack of tephras in the thin soil cover, the dates agree remarkably well with the CI-T data from Myfluguvatn and our data set would suggest that a relative decline in summer temperatures by $1.5-2.0^{\circ} \mathrm{C}$ (albeit associated with unknown changes in precipitation regimes) was enough to instigate significant LIA glacial advances. A direct glacial response to changes in summer temperature would not necessarily be unexpected though, as Stötter et al. (1999) argue that when climatic conditions become colder in N and NW Iceland the climate also becomes drier.

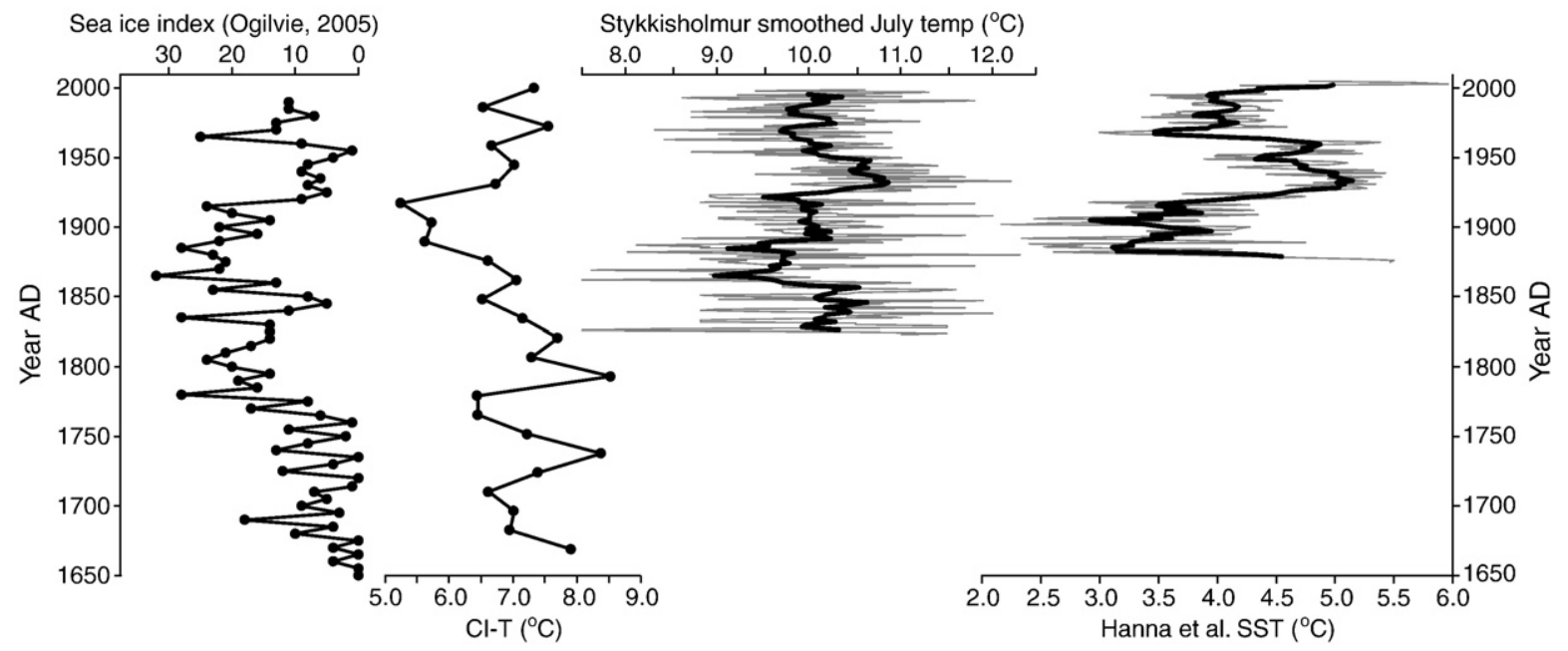

Figure 8. CI-T compared with Stykkishólmur instrumental July temperature data, Hanna et al. (2006) sea ice composite record, and the Ogilvie (2005) sea ice reconstruction. Meteorological data are from Veðurstofa Íslands, http://www.vedur.is. 
Furthermore, our data appear to validate modelling experiments of initiating LIA glacial maxima as experiments on the Langjökull ice cap suggest that in order to develop the peak LIA ice margins summer temperatures needed to be $1-2^{\circ} \mathrm{C}$ cooler than the 1961-1990 AD average (Flowers et al., 2007). Indeed most glaciers in Iceland reached their maximum Holocene extent during the LIA (Grove, 1988; Bradwell, 2001, 2004; Geirsdóttir et al, 2009a) suggesting this may have been the most consistently cool period throughout the Holocene. A longer sequence from this site would reveal whether the site was ever cold enough in previous periods of the Holocene to support the fauna observed during these cold episodes of the LIA.

The chironomid-based reconstruction identifies clear phases where temperatures are cooler than present, as discussed above, but it also shows temperatures warmer than present around AD 1740 and AD 1790. Interpreting these temperatures as absolute values, i.e. periods in the $18^{\text {th }}$ century were warmer than present, should be done with extreme caution as both of these warm points are represented solely by a single sample. In addition, both samples contain relatively large proportions of rheophiles, notably Rheocricotopus and Chaetocladius, which could be the result of hydrological changes affecting the lake rather than solely summer temperatures. Detailed analyses of these periods at higher resolution, taking 0.25 or $0.5 \mathrm{~cm}$ subsamples, would help ascertain whether absolute temperatures during parts of the $18^{\text {th }}$ century were warmer or not than present.

Palaeoclimate sequences have been produced from other lacustrine sites in NW Iceland, but all from lower altitudes (Doner, 2003; Caseldine et al., 2003; Geirsdóttir et al., 2009b). Axford et al. (2009) produced temperature estimates from a chironomid sequence in NE Iceland through a comparison of the detrended correspondence analysis (DCA) scores with instrumental data, and then applied the relationships to the other fossil data. They showed that the coolest conditions over the last 2000 years occurred in the $18^{\text {th }}$ and $19^{\text {th }}$ centuries, with a drop in average summer temperatures from the preceding millennium of $1-2^{\circ} \mathrm{C}$, although the data resolution and dating controls did not allow further details to be defined. The study of Geirsdóttir et al. (2009b) used proxies for productivity (biogenic silica - BSi and total organic carbon - TOC) and related them to spring temperature and cold/windy summers, respectively. Their reconstructions suggested significant cold periods from AD 1450 for ca. 100 years and from ca. AD 1730-1780, the latter of which agrees well with our record.

Offshore data have also been used to estimate the magnitude, timing and rate of climate change over the LIA period. Data sets from the North Icelandic shelf show general patterns of surface and bottom water cooling initiated between AD 1200 and 1350, with intensification of cooling after AD 1550-1600 (e.g. Castañeda et al., 2004; Jiang et al., 2005; Andresen et al., 2005; Eiríksson et al., 2006; Massé et al., 2008; Andrews et al., 2009) due to a relative greater contribution of polar waters as opposed to Atlantic waters (Jiang et al., 2007). While the broad scale changes are in accordance with the terrestrial records, as noted by Andrews et al. (2009), suggesting close coupling between the marine and atmospheric temperatures, in general the majority of marine cores lack the temporal resolution to compare with detailed terrestrial reconstructions. Some high resolution data sets exist, however, and sea surface temperatures (Jiang et al., 2007) and $\mathrm{IP}_{25}$ abundance (a new sea-ice algae biomarker) (Massé et al., 2008) do show good agreement with the Myfluguvatn CI-T record.

While the chironomids clearly respond to temperature changes at Myfluguvatn, it is worth noting that there is no evidence for any significant changes in the catchment from the chemistry data (Fig. 7). The Myfluguvatn catchment comprises bare rock and some patches of thin soils with grass and/or moss vegetation, and the paucity of any geochemical evidence for enhanced catchment erosion, even during the coldest phases of the LIA, may be related to the lack of any (long-term) anthropogenic catchment disturbance. Other studies on lowland lakes in Iceland suggest that climate changes during the LIA have had a clear impact on their catchments, usually in the form of soil degradation and subsequent erosion (e.g. Doner, 2003; Geirsdóttir et al., 2009b; Gathorne-Hardy et al., 2009). These sites have been previously exposed to loss of woodland and associated soil erosion, which began either around or even before settlement (Geirsdóttir et al., 2009b), and hence the contemporary and/or recent erosion is likely to be a legacy of anthropogenic impacts (Dugmore et al., 2000; McGovern et al., 2007), as the landscape is less resilient to (natural) climate change than prior to settlement (cf. Dearing, 2008).

\section{Conclusions}

Model validation is a crucial aspect of determining the usefulness of space-for-time substitution approaches (or transfer functions) for reconstructing past climate change. This study shows that a chironomid-based summer temperature reconstruction, through a transfer function approach, from a relatively high-altitude lake in Iceland correlates well with instrumental temperatures over a period of ca. 150 years. Variations in magnitude from the reconstruction agree well with modelling studies undertaken to estimate the temperature cooling needed to generate LIA glacial maxima, and can be used for producing proxy data that are sensitive to both warm and cold changes. As such this is an important site for producing quantitative temperature reconstructions which can be used for North Atlantic palaeoclimate syntheses on a range of timescales and is a potential valuable source for the Holocene as a whole. The palaeoclimate record produced here will be useful for testing emerging hypotheses regarding forcings and dynamics of LIA climate around the North Atlantic.

\section{Acknowledgments}

The authors would like to thank Jon Olafsson, Thora Hrafnsdóttir and Naomi Holmes for discussions on Icelandic subfossil chironomid taxonomy, Guðrun Larsen and Siwan Davies for assistance with the tephra analyses, and Dr. Chris Hayward for his assistance with the use of the electron microprobe at the Tephrochronology Analytical Unit, University of Edinburgh. NERC-BOSCORF are thanked for providing access to the Itrax core scanner. Jerry Lloyd is thanked for his assistance in the field, and Astrid Ogilvie for the sea ice record. Funding for this work came through the Vatnsfjordur project, for which we thank Karen Milek, and also the EU funded 'Millennium' project (Millennium 017008). Bob Smith from the Cartographic Unit, University of Southampton is thanked for drawing Figure 1. Tom Marchitto and two anonymous reviewers are thanked for their insightful comments on an earlier version of the manuscript.

\section{References}

Andresen, C.S., Bond, G., Kuijpers, A., Knutz, P.C., Björck, S., 2005. Holocene climate variability at multidecadal time scales detected by sedimentological indicators in a shelf core NW off Iceland. Marine Geology 214, 323-338.

Andrews, J.T., Belt, S.T., Olafsdottir, S., Massé, G., Vare, L.L., 2009. Sea ice and marine climate variability for NW Iceland/Denmark Strait over the last $2000 \mathrm{cal}$. yr BP. The Holocene $19,775-784$

Appleby, P.G., Oldfield, F., 1978. The calculation of $210 \mathrm{~Pb}$ dates assuming a constant rate of supply of unsupported $210 \mathrm{~Pb}$ to the sediment. Catena $5,1-8$.

Axford, Y., Miller, G.H., Geirsdóttir, Á., Langdon, P.G., 2007. Holocene temperature history of northern Iceland inferred from subfossil midges. Quaternary Science Reviews 26 (3344), 3358.

Axford, Y., Geirsdóttir, Â., Miller, G.H., Langdon, P.G., 2009. Climate of the Little Ice Age and the past 2000 years in Northeast Iceland inferred from chironomids and other lake sediment proxies. Journal of Paleolimnology 41, 7-24.

Barley, E.M., Walker, I.R., Kurek, J., Cwynar, L.C., Mathewes, R.W., Gajewski, K., Finney, B.P., 2006. A northwest North American training set: distribution of freshwater midges in relation to air temperature and lake depth. Journal of Paleolimnology 36, 295-314.

Battarbee, R.W., 2000. Palaeolimnological approaches to climate change, with special regard to the biological record. Quaternary Science Reviews 19, 107-124.

Bradwell, T., 2001. A new lichenometric dating curve for southwest Iceland. Geografiska Annaler 83A, 91-101.

Bradwell, T., 2004. Lichenometric dating in southeast Iceland: the size-frequency approach. Geografiska Annaler 86A, 31-41. 
Brodersen, K.P., Quinlan, R., 2006. Midges as palaeoindicators of lake productivity, eutrophication and hypolimnetic oxygen. Quaternary Science Reviews 25, 1995-2012.

Brooks, S.J., 2000. Late-glacial fossil midge stratigraphies (Insecta: Diptera: Chironomidae) from the Swiss Alps. Palaeogeography, Palaeoclimatology, Palaeoecology 159, 261-279.

Brooks, S.J., 2006. Fossil midges (Diptera: Chironomidae) as palaeoclimatic indicators for the Eurasion region. Quaternary Science Reviews 25, 1894-1910.

Brooks, S.J., Birks, H.J.B., 2004. The dynamics of Chironomidae (Insecta: Diptera) assemblages in response to environmental change during the past 700 years on Svalbard. Journal of Paleolimnology 31, 483-498.

Brooks, S.J., Langdon, P.G., Heiri, O., 2007. The identification and use of Palaearctic Chironomidae Larvae in Palaeoecology. QRA Technical Guide No. 10. Quaternary Research Association, London. 276 pp.

Caseldine, C.J., Geirsdóttir, Á., Langdon, P.G., 2003. Efstadalsvatn-a multi-proxy study of a Holocene lacustrine sequence from NW Iceland. Journal of Paleolimnology 30 , $55-73$

Caseldine, C.J., Langdon, P.G., Holmes, N., 2006. Early Holocene climate variability and the timing and extent of the Holocene Thermal Maximum (HTM) in Northern Iceland. Quaternary Science Reviews 25, 2314-2331.

Castañeda, I.S., Smith, L.M., Kristjánsdóttir, G.B., Andrews, J.T., 2004. Temporal changes in Holocene $\delta 180$ records from the northwest and central North Iceland shelf. Journal of Quaternary Science 19, 321-334.

Croudace, I., Rindby, A., Rothwell, R, 2006. ITRAX: description and evaluation of new multi function X-ray core scanner. In: Rothwell, R.G. (Ed.), New techniques in sediment core analysis: Geological Society London Special Publication, 267, pp. 51-63.

Dean Jr., W.E., 1974. Determination of carbonate and organic matter in calcareous sediments and sedimentary rocks by loss on ignition: comparison with other methods. Journal of Sediment Petrology 44, 242-248.

Dearing, J.A., 2008. Landscape change and resilience theory: a palaeoenvironmental assessment from Yunnan, SW China. The Holocene 18, 117-127.

Doner, L., 2003. Late-Holocene paleoenvironments of northwest Iceland from lake sediments. Palaeogeography, Palaeoclimatology, Palaeoecology 193, 535-560.

Dugmore, A.J., Larsen, G., Newton, A.J., 1995. Seven tephra isochrones in Scotland. The Holocene 5, 257-266.

Dugmore, A.J., Newton, A.J., Larsen, G., Cook, G.T., 2000. Tephrochronology, environmental change, and the Norse colonisation of Iceland. Environmental Archaeology 5, 21-34.

Dugmore, A.J., Church, M.J., Mairs, K.A., McGovern, T.H., Perdikaris, S., Vesteinsson, O 2007. Abandoned farms, volcanic impacts, and woodland management: revisiting pjórsárdalur, the "Pompeii of Iceland". Arctic Anthropology 44, 1-11.

Eiríksson, J., Bartels-Jónsdóttir, H.B., Cage, A.G., Gudmundsdóttir, E.R., Klitgaard-Kristensen, D., Marret, F., Rodrigues, T., Abrantes, F., Austin, W.E.N., Jiang, H., Knudsen, K.-L., Sejrup, H.-P., 2006. Variability of the North Atlantic Current during the last 2000 years based on shelf bottom water and sea surface temperatures along an open ocean/shallow marine transect in western Europe. The Holocene 16, 1017-1029.

Esper, J., Cook, E.R., Schweingruber, F.H., 2002. Low-frequency signals in long tree-ring chronologies and the reconstruction of past temperature variability. Science 295 $2250-2253$.

Flowers, G.E., Björnsson, H., Geirsdóttir, Á., Miller, G.H., Clarke, G.K.C., 2007. Glacier fluctuation and inferred climatology of Langjökull ice cap through the Little Ice Age. Quaternary Science Reviews 26, 2337-2353.

Flynn, W.W., 1968. Determination of low levels of polonium-210 in environmental materials. Analytica Chimica Acta 43, 221-227.

Gathorne-Hardy, F.J., Erlendsson, E., Langdon, P.G., Edwards, K.J., 2009. Lake sediment evidence for late-Holocene climate change and landscape erosion in western Iceland. Journal of Paleolimnology 42, 413-426.

Geirsdóttir, Á., Miller, G.H., Axford, Y., Ólafsdóttir, S., 2009a. Holocene and latest Pleistocene climate and glacier fluctuations in Iceland. Quaternary Science Reviews $28,2107-2118$.

Geirsdóttir, Á., Miller, G.H., Thordarson, T., Ólafsdóttir, K., 2009b. A 2000 year record of climate variations reconstructed from Haukadalsvatn, West Iceland. Journal of Paleolimnology 41, 95-115.

Grove, J.M., 1988. The Little Ice Age. Methuen, London. 498 pp.

Hanna, E., Jónsson, T., Ólafsson, J., Valdimarsson, H., 2006. Icelandic coastal sea-surface temperature records constructed: putting the pulse on air-sea-climate interactions in the northern North Atlantic. Part 1: comparison with HadISST1 open ocean surface temperatures and prelimuinary analysis of long-term patterns and anomalies of SSTs around Iceland. Journal of Climate 19, 5652-5666.

Heiri, O., Lotter, A.F., Hausmann, S., Kienast, F., 2003. A chironomid-based Holocene summer air temperature reconstruction from the Swiss Alps. The Holocene 13, 477-484.

Holmes, N., 2006. Evaluating the use of subfossil chironomids for the reconstruction of Holocene climate in N and NW Iceland. Ph.D. Dissertation, University of Exeter, Exeter, UK, $374 \mathrm{pp}$

Hrafnsdóttir, Th., 2005. Diptera 2 (Chironomidae). Zoology of Iceland III 48b, 1-169.

Jiang, H., Eiríksson, J., Schulz, M., Knudsen, K.L., Seidenkrantz, M.S., 2005. Evidence for solar forcing of sea-surface temperature on the North Icelandic Shelf during the late Holocene. Geology 33, 73-76.

Jiang, H., Ren, J., Knudsen, K.L., Eiríksson, J., Ran, L., 2007. Summer sea-surface temperatures and climate events on the North Icelandic shelf through the last 3000 years. Chinese Science Bulletin 52, 789-796.
Juggins, S., 2003. C2 User guide. Software for ecological and palaeoecological data analysis and visualisation. University of Newcastle, UK.

Kirkbride, M.P., Dugmore, A.J., 2006. Responses of mountain ice caps in central Iceland to Holocene climate change. Quaternary Science Reviews 25, 1692-1707.

Korhola, A., Birks, H.J.B., Olander, H., Blom, T., 2001. Chironomids, temperature and numerical models: a reply to Seppälä. The Holocene 11, 615-622.

Langdon, P.G., Barber, K.E., Lomas-Clarke (previously Morriss), S.H., 2004. Reconstructing climate and environmental change in Northern England through chironomid and pollen analyses: evidence from Talkin Tarn, Cumbria. Journal of Paleolimnology 32, 197-213.

Langdon, P.G., Ruiz, Z., Brodersen, K.P., Foster, I.D.L., 2006. Assessing lake eutrophication using chironomids: understanding the nature of community response in different lake types. Freshwater Biology 51, 562-577.

Langdon, P.G., Holmes, N., Caseldine, C.J., 2008. Environmental controls on modern chironomid faunas from NW Iceland and implications for reconstructing climate change. Journal of Paleolimnology 40, 273-293.

Larocque, I., Hall, R.I., 2003. Chironomids as quantitative indicators of mean July air temperature: validation by comparison with century-long meteorological records from northern Sweden. Journal of Paleolimnology 29, 475-493.

Larocque, I., Hall, R.I., Grahn, E., 2001. Chironomids as indicators of climate change: 100-lake training set from a subarctic region of northern Sweden (Lapland). Journal of Paleolimnology 26, 307-322.

Larocque, I., Grosjean, M., Heiri, O., Bigler, C., Blass, A., 2009. Comparison between chironomid inferred July temperatures and meteorological data AD 1850-2001 from varved Lake Silvaplana, Switzerland. Journal of Paleolimnology 41 329-342.

Larsen, G., Dugmore, A., Newton, A., 1999. Geochemistry of historical-age silicic tephras in Iceland. The Holocene 9, 463-471.

Larsen, G., Eiríksson, J., Knudsen, K., Heinemeier, J., 2002. Correlation of Late Holocene terrestrial and marine tephra markers, north Iceland: implications for reservoir age changes. Polar Research 21, 283-290.

Lindegaard, C., 1992. Zoobenthos ecology of Thingvallavatn: vertical distribution abundance, population dynamics and production. Oikos 64, 257-304.

Luoto, T.P., Nevalainen, L., Sarmaja-Korjonen, K., 2008. Multiproxy evidence for the 'Little Ice Age' from Lake Hampträsk, Southern Finland. Journal of Paleolimnology 40, 1097-1113.

Luoto, T.P., Sarmaja-Korjonen, K., Nevalainen, L., Kauppila, T., 2009. A 700 year record of temperature and nutrient changes in a small eutrophied lake in southern Finland. The Holocene 19, 1063-1072.

Massé, G., Rowland, S.J., Sicre, M.-A., Jacob, J., Jansen, E., Belt, S.T., 2008. Abrupt climate changes for Iceland during the last millennium: evidence from high resolution sea ice reconstructions. Earth and Planetary Science Letters 269, 565-569.

McGovern, T.H., Vésteinsson, O., Friðriksson, A., Church, M., Lawson, I., Simpson, I.A., Einarsson, A., Dugmore, A., Cook, G., Perdikaris, S., Edwards, K.J., Thomson, A.M., Adderley, W.P., Newton, A., Lucas, G., Edvardsson, R., Aldred, O., Dunbar, E., 2007. Landscapes of settlement in Northern Iceland: historical ecology of human impact and climate fluctuation on the millennial scale. American Anthropologist 109, $27-51$.

Ogilvie, A.E.J., 1984. The past climate and sea-ice record from Iceland, Part 1: data to AD 1780. Climatic Change 6, 131-152.

Ogilvie, A.E.J., 2005. Local knowledge and travellers' tales: a selection of climatic observations in Iceland. Iceland-modern processes and past environments. Developments in Quaternary Science, 5. Elsevier, Amsterdam-Boston-HeidelbergLondon, pp. 257-287.

Ogilvie, A.E.J., Jónsson, T., 2001. “Little Ice Age” research: a perspective from Iceland. Climatic Change 48, 9-52.

Parker, D.E., Legg, T.P., Folland, C.K., 1992. A new daily central England temperature series. International Journal of Climatology 12, 317-342.

Ritchie, J.C., McHenry, J.T., 1990. Application of fallout Cs-137 for measuring soil erosion and sediment accumulation rates and patterns: a review. Journal of Environmental Quality 19, 215-233.

Robbins, J.A., 1978. Geochemical and geophysical applications of radioactive lead isotopes. In: Nriagu, J.O. (Ed.), Biochemistry of Lead. Elsevier, Amsterdam, pp. 285-393.

Sayer, C.D., Davidson, T.A., Jones, J.I., Langdon, P.G., 2010. Combining contemporary ecology and palaeolimnology to understand shallow lake ecosystem change. Freshwater Biology 55 (487), 499.

Stötter, J., Wastl, M., Caseldine, C., Häberle, T., 1999. Holocene palaeoclimatic reconstructions in Northern Iceland: approaches and results. Quaternary Science Reviews 18, 457-474

ter Braak, C.J.F., Smilauer, P., 1998. CANOCO Reference Manual and User's Guide to Canoco for Windows: Software for Canonical Community Ordination (version 4.5.2) Microcomputer Power, Ithaca.

Turney, C.S.M., 1998. Extraction of rhyolitic component of Vedde microtephra from minerogenic lake sediments. Journal of Paleolimnology 19, 199-206.

Wastegård, S., Davies, S.M., 2009. An overview of distal tephrostratigraphy in Northern Europe during the last 1000 years. Journal of Quaternary Science 24, 500-512.

Wastegård, S., Hall, V.A., Hannon, G.E., van den Bogaard, C., Pilcher, J.R., Sigurgeirsson, M.Á., Hermanns-Audardóttir, M., 2003. Rhyolitic tephra horizons in northwestern Europe and Iceland from the AD 700s-800s: a potential alternative for dating first human impact. The Holocene 13, 277-283. 